\title{
Agri-Environmental Policy Measures in Israel: The Potential of Using Market-Oriented Instruments
}

\author{
Liron Amdur • Elke Bertke • Jan Freese • \\ Rainer Marggraf
}

Received: 12 August 2009/Accepted: 25 February 2011/Published online: 23 March 2011

(C) The Author(s) 2011. This article is published with open access at Springerlink.com

\begin{abstract}
This paper examines the possibilities of developing agri-environmental policy measures in Israel, focusing on market-oriented instruments. A conceptual framework for developing agri-environmental policy measures is presented, first in very broad lines (mandatory regulations, economic instruments and advisory measures) and subsequently focusing on economic instruments, and specifically, on market-oriented ones. Two criteria of choice between the measures are suggested: their contribution to improving the effectiveness of the policy; and the feasibility of their implementation. This is the framework used for analyzing agri-environmental measures in Israel. Israel currently implements a mix of mandatory regulations, economic instruments and advisory measures to promote the agri-environment. The use of additional economic instruments may improve the effectiveness of the policy. When comparing the effectiveness of various economic measures, we found that the feasibility of implementation of market-oriented instruments is greater, due to the Israeli public's preference for strengthening market orientation in the agricultural sector. Four market-oriented instruments were practiced in a pilot project conducted in an Israeli rural area. We found that in this case study, the institutional feasibility and acceptance by stakeholders were the major parameters influencing the implementation of the market-oriented instruments, whereas the instruments' contribution to enhancing the ecological or
\end{abstract}

L. Amdur $(\bowtie) \cdot$ E. Bertke $\cdot$ J. Freese $\cdot$ R. Marggraf Section for Environmental and Resource Economics, Department of Agricultural Economics and Rural Development, University of Göttingen, Platz der Göttinger Sieben 5, Göttingen 37073, Germany

e-mail: liron_am@hotmail.com economic effectiveness were hardly considered by the stakeholders as arguments in favor of their use.

Keywords Agri-environmental policy .

Agri-environmental schemes - Market-orientation ·

Result-orientation - Conservation auctions .

Institutional feasibility

\section{Introduction}

As agriculture occupies close to $40 \%$ of the world's land area, its impact on environmental resources is considerable. In order to guide this influence, many countries have established diverse policy measures, including mandatory regulations, economic instruments and advisory measures. Agri-environmental payment schemes comprise a central economic instrument. Although these schemes vary markedly between countries, they mostly share the same core concept: farmers are paid to modify their cultivation or livestock husbandry in order to protect, maintain or support environmental resources (Engel and others 2008; OECD 2005; Smith 2006).

Recently, the integration of market economy components into these schemes has been advocated by academics and policy makers (Gerowitt and others 2003a, b; Hampicke 2006). Market-oriented instruments are supposed to improve the ecological and economic effectiveness of the schemes (Kleijn and others 2006; Kleijn and Sutherland 2003; Marggraf 2003; von Haaren and Bathke 2008; von Haaren and Bills 2007).

Agri-environmental policy measures are now being practiced in developed, as well as developing countries (Ferraro 2009; Wunder and others 2008), and it is probable that they will be introduced into an ever growing number of 
countries. The challenges of developing agri-environmental policy measures, and especially market-oriented ones, are explored here, using Israel as a case study. The experience gained in other countries, especially in the EU, will be used as a benchmark.

The comparison between the agri-environmental policies of the EU and Israel seems at first glance questionable, as the EU is a much larger entity than the State of Israel, and practices a highly heterogeneous agri-environmental policy. However, as some agri-environmental policies in the EU are implemented on a small scale (e.g., in a German federal state or a small EU-member state like Luxembourg or Slovenia), their relevancy to Israel seems justified. Without question, the policy of the EU is more complex, but some of its aims and instruments are highly relevant to Israel.

The paper proposes a conceptual framework for developing agri-environmental policy measures, and then follows this framework when reflecting on the current agri-environmental policy in Israel and potential future alternatives that were explored in a pilot project, with references to the experience acquired in the EU and other countries.

\section{Conceptual Framework}

The paper is organized as a discussion on how to choose policy measures in order to address agri-environmental problems. Our conceptual framework is detailed in Fig. 1. We start our discussion in very broad terms, presenting the three main avenues of policy interventions that a government may implement in order to tackle the agri-environment issue: mandatory regulations, economic instruments and advisory measures. Once the economic measures are selected, the policy maker is presented with a range of economic instruments to choose from. These include: centrally-planned payment schemes, market-oriented schemes, taxes and charges, eco-labeling, tradable permits, etc.

The main economic agri-environmental measures that will be considered in this paper are centrally-planned payment schemes and market-oriented payment schemes. The first forms the widespread agri-environmental payment model, which has been practiced in the EU for about two decades (Baylis and others 2008; Dobbs and Pretty 2004; European Commission 2005, 2006; Kleijn and Sutherland 2003). According to this model, farmers voluntarily take upon themselves environmental commitments in exchange for payment set by the authorities. A market-oriented payment scheme, in contrast, is a decentralized model that emphasises competition between farmers for the delivery of environmental services, and local decisions over the economic parameters of the scheme. This innovative approach, as will be detailed later in this paper, is currently practiced in some countries and regions within mainstream policy, as well as in experimental settings (Bertke and others 2005; Klimek and others 2008; von Haaren and Bathke 2008; Wittig and others 2006).

As we proceed, we examine a range of market-oriented agri-environmental instruments. These include result-orientation, conservation auctions, participatory approach in setting the economic parameters of the scheme and local organization. These instruments will be detailed later in the paper and their advantages and disadvantages discussed.

We suggest two criteria of choice between agri-environmental policy measures: effectiveness-does the policy measure improve the ability to achieve the requested results?; and feasibility-does the policy measure stand a good chance of being implemented?. We classify these criteria into a number of sub-criteria: the sub-criteria of effectiveness are ecological effectiveness-does the policy measure improve the ecological results?; and economic effectiveness-does the measure improve the ability to achieve the results at minimum costs? The sub-criteria of feasibility are: institutional feasibility-does the measure fit the existing governmental institutions, regulations etc.?; acceptance by farmers-are the farmers willing to support the implementation of the measure?; and acceptance by the public at large-does the measure fit the public understanding of the way the agri-environment should be addressed?. These criteria of choice seem to be relevant to all levels of the conceptual framework.

We examine this conceptual framework in the Israeli case, looking into various decision cross-roads in the design of agri-environmental policy in this country, and reflecting on lessons learned within previous cases in the EU and other places.

\section{Methods}

The findings presented here are based on an analysis of a multitude of sources, relating to both the European and the Israeli cases. These include the study of documents, such as government reports, statistical data, master plans and position papers issued by various organizations. In addition, the study builds on the involvement of one author ( $\mathrm{L}$. Amdur) in a process led by academics and professionals in Israel aiming to establish agri-environmental payment schemes; this involvement enabled gaining insights and interpretations of stakeholders' opinions. The analysis of the market-oriented agri-environmental instruments, as practiced in the EU, is also based on the authors' experience in the implementation of a market-oriented agrienvironmental scheme as a pilot project, among other sources. 
Fig. 1 A conceptual framework for developing agri-environmental policy measures

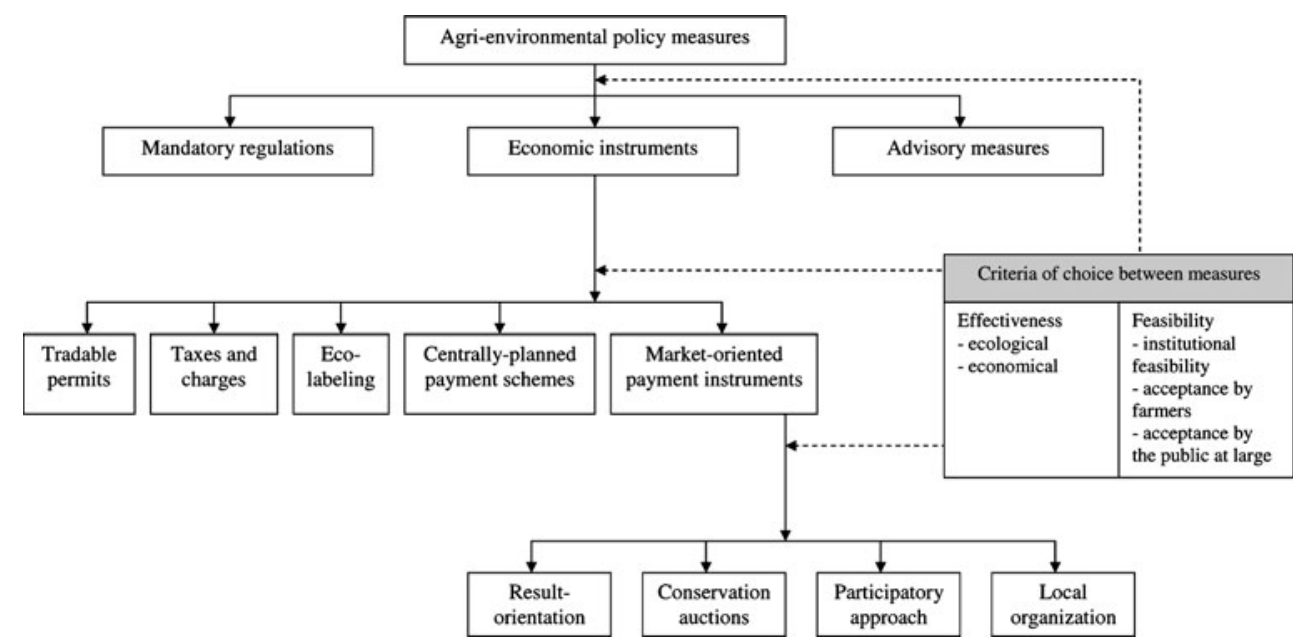

The examination of the potential of using market-oriented agri-environmental instruments in Israel is based on a pilot project conducted in 2008-2009 at the Megido Regional Council. This is a rural authority located in northern Israel and consisting of 13 villages, 9 of which are communal villages (kibbutzim) and 4 are family-farms villages (moshavim). Altogether, there are around 35 active farms in this regional authority, including the communal farms of the kibbutzim, together cultivating around 3,600 hectares (ICBS 2008). Most of the area of the regional council is designated for nature reserves and national parks; recently, this council initiated the designation of its entire geographical area as a biosphere reserve.

The undulating topography of the terrain, combined with intensive field-crops cultivation, leads to problems of soil erosion. In order to mitigate the soil erosion, the Ministry of Agriculture has developed a plan to convert crop fields into fruit tree plantations, as a means of establishing permanent vegetation on the fields and benefiting from the soil protection offered by the trees' canopies. The pilot project was integrated into this general plan. As olive groves were found to contribute to biodiversity protection (Pe'er and others 2006) and were preferred by the Israeli public owing to their visual quality (Misgav 2000), they were chosen as the type of plantation to be promoted within the framework of the project. When cultivated with grass cover between the rows of trees, the erosion in the olive groves is minimized (Gomez and others 2004); this form of soil management was included in the guidelines for cultivating the groves within the pilot project.

Based on the project managers' understanding of the current political atmosphere in Israel, it was decided to use market-based agri-environmental instruments in the pilot project. The reasoning for this choice will be discussed in depth later in this paper.
Our study consisted of in-depth interviews with the pilot project stakeholders, using open-ended questions and follow-up probes. The interviews focused on understanding the current institutional framework relating to agri-environment in Israel, as well as the interviewees' attitudes towards agrienvironmental schemes and the market-oriented components proposed within the pilot project. The intention was to interview all the relevant stakeholders of the project. Altogether, 30 stakeholders were interviewed: these included all the farming managers in kibbutzim and moshavim (12 interviewees, 11 of which were men). All active family farmers in the regional council were contacted, however only 9 ( 8 of which were men) were relevant for the project (i.e., cultivated crops) and were willing to be interviewed. In addition, all the members of the project's steering committee, consisting of local and national level decision makers with either agricultural, planning or environmental orientations, were interviewed (a total of 9 interviewees). As performing a large survey of public attitudes was beyond the scope of this study, we will consider here the attitudes of the policy makers as reflecting (to a certain extent) those of the public at large.

The interviews with the farmers were structured as follows: first their perception of agri-environmental services, and their attitude towards public remuneration of these services, were discussed. Subsequently, the framework of the pilot project was presented and discussed, focusing on the farmers' attitudes towards the market-oriented components included in the project. The interviews with the policy makers followed the same lines, and furthermorethe integration of market-oriented instruments into the administrative operations in Israel was discussed. The interviews lasted 45 minutes to 2 hours each. In addition, the meetings of the project's steering committee and a public hearing in which 20 farmers participated were recorded and analyzed. 
The interviews and meetings were recorded and analyzed using MAXQDA2007 software. This software assists in assigning codes to text segments, and in their retrieval according to codes, interviewee's attributes, etc.

\section{Protecting the Agri-Environment in Israel: Mandatory Regulations, Economic Instruments or Advisory Measures?}

The Necessity of Supporting the Agri-Environment in Israel

Arable land comprises approximately $25 \%$ of the total area of Israel (ICBS 2006). Agriculture currently plays a minor role in this country, both economically and as a way of life. Only $1.8 \%$ of the country's total net domestic product derives from cultivation (although related industries account for a larger share of the economy), only $2 \%$ of the labor force is employed in agriculture, and less than $9 \%$ of the population lives in rural areas (ICBS 2006). Israel imports a large share of the food required to fill its consumption needs (ICBS 2006); "food independence" is hardly achievable given the local semi-arid climate and the population size of over 7 million.

Israel is a highly urbanized country. More than $90 \%$ of the population resides in urban settlements (ICBS 2006), in comparison with $50 \%$ of the population in the EU (EU 2003). The population density in Israel is relatively high: around 305 people $/ \mathrm{km}^{2}$ (ICBS 2006), as is the population growth rate (1.9\% annually during 2001-2005). From the mid-1980s, a gradual process began, in which the economic viability of local agriculture declined, while urbanization of the core area sharply increased. This led to the perception of agricultural fields less as a source of livelihood for the farmers and more as suppliers of open space amenities to urban dwellers (Feitelson 1999). Most of the open areas surrounding the urbanized core in Israel are designated for agriculture, whereas nature reserves, national parks or protected forests are located at a greater distance (Fig. 2). Willingness-to-pay surveys identify a steady demand for the aesthetic amenities of agricultural landscapes in Israel (Fleischer and others 1997; Shemesh-Adani 2003; Shirizly 2001). The values obtained within the framework of different studies are in the same range, demonstrating that the Israeli public is consistent in its demand for agri-environmental visual amenities (see Table 1). Moreover, some studies found that the Israeli public prefers the visual qualities of agricultural fields or plantations to those of Mediterranean savannas or Garrigue (Misgav 2000; Shirizly 2001), which comprise the landscape that will probably develop if cultivation is abandoned, at least in the short and medium term (Preiss and others 1997).
Other agri-environmental services that were studied in the Israeli context include protection of biodiversity (Pe'er and others 2006), improved infiltration of rainwater into ploughed land, absorption of organic solid waste and treated wastewater (Zaban and others 2004). Zaban and others (2004) estimated the total value of the environmental services of the Israeli agriculture at US\$ 730 per hectare.

The necessity of supporting the agri-environment in Israel derives from the need to mitigate threats to the supply of agri-environmental services and the negative impact of agriculture on the environment.

The threats to the supply of agri-environmental services emerge from processes of urbanization and abandonment

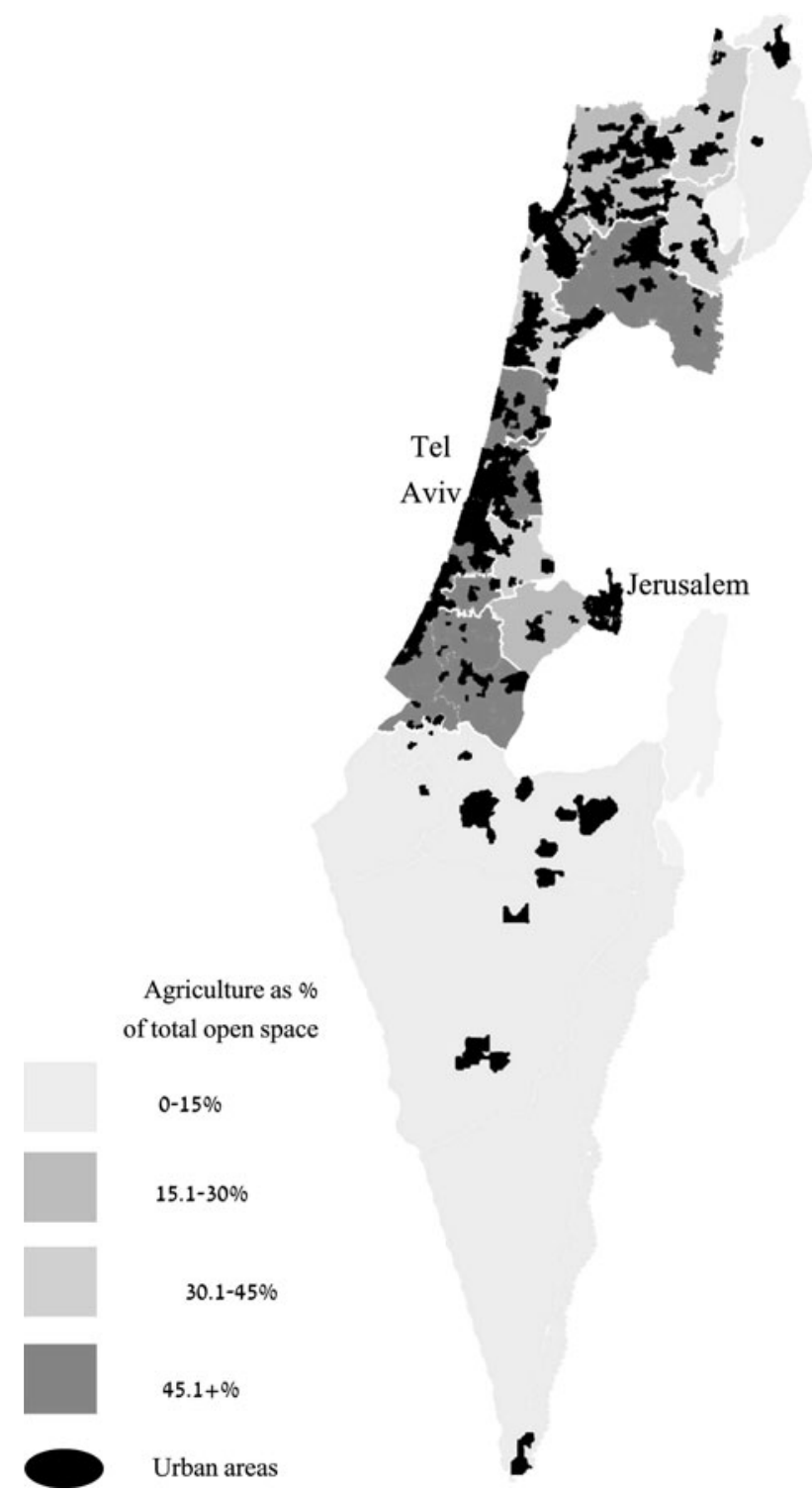

Fig. 2 Agriculture in proximity to Israeli urban areas. Source of map: Authors, based on data of the Israeli Central Bureau of Statistics (2002) 
Table 1 The Israeli public's willingness-to-pay for aesthetic qualities of landscape types, findings of previous studies

\begin{tabular}{ll}
\hline Source & WTP (NIS) \\
\hline Shemesh-Adani (2003) & $64.10-43.06$ \\
Shirizly (2001) & 29.80 \\
Fleischer and others (1997) & $54.76-27.99$ \\
Total range & $29.8-64.10$ \\
\hline
\end{tabular}

${ }^{a}$ NIS is the Israeli currency. All the values relate to a one-time donation for preserving the landscape, and are inflation-adjusted for 2005

of fields. Around $65 \%$ of the development in Israel takes place at the expense of agricultural land (Frenkel 2001). In the labor market, only $12 \%$ of rural employment presently remains in agriculture, in comparison with $31 \%$ in 1984 (Sofer and Applebaum 2006). The abandonment of agricultural cultivation is widespread, as approximately $13 \%$ of the agricultural land in the country has not been farmed for long periods of time, and there are no plans for its re-cultivation (Gal 2003; MOAG 2004).

In the Israeli context-abandoned land produces lower environmental services than cultivated fields. As mentioned above, the Israeli public prefers the aesthetic value of cultivated land to that of abandoned land. Un-ploughed land exhibits poorer hydrological behavior, including a lower infiltration rate (Lasanta and others 2000; Poyatos and others 2003). Evidence from a number of Mediterranean countries demonstrates that abandonment of cultivation may lead to loss of habitats, creation of a lasting phase of stressful conditions to the local ecosystem, and therefore-detrimental effects to local biodiversity (Poyatos and others 2003; Preiss and others 1997; Romero-Calcerrada and Perry 2004; Scozzafava and de Sanctis 2006).

As in many other places, Israeli agriculture also has a negative impact on the environment, including impact associated with the use of chemical fertilizers and pesticides; erosion due to cultivation; loss of habitats and connectivity between open spaces due to construction of greenhouses and agricultural buildings; etc.

Protecting the Agri-Environment in Israel: To Strengthen the Use of Economic Instruments?

Currently, Israel implements a mix of mandatory regulations, economic instruments and advisory measures to address a wide range of agri-environmental issues, including protection of farmland against construction; support of cultivation activities to prevent abandonment; and mitigation of the negative impact of farming on the environment.
The mechanisms that aim to protect Israeli farmland against construction are based on mandatory regulations. These include zoning and the activities of a special commission-the Commission for Protection of Agricultural Land (CPAL) (Feitelson 1999). Zoning is performed by master plans at the national, regional and local levels, which determine which land cannot be used for development. In addition, the CPAL holds veto power over plans to change the designation of farmland into land for construction (Egoz 1996). These regulative instruments are supported by an economic instrument integrated into the land tenure system, which states that a lessee of stateowned agricultural land (approximately 90\% of farmland in Israel) cannot financially gain from its development. Although these mechanisms were weakened over the years, they are still powerful in protecting the Israeli farmland against construction.

The policy instruments that support cultivation activities against abandonment are also based on mandatory regulations and economic instruments. The mandatory regulations are integrated into the terms of lease of state-owned farmland, which state that when the lessee stops cultivating the land for longer than 3 years, the state may terminate the contract and lease the land to another farmer. However, this regulation has rarely been enforced (Gal 2003), among other reasons, because the farmer's house is considered an integral part of the farm, and terminating the contract on the farm means removing the farmer's family from its home-an act that Israeli officials are reluctant to perform.

In addition to this mandatory regulation, Israel promotes agricultural cultivation through financial support for farmers. In recent years this support has been relatively modest, amounting to approximately $3 \%$ of the value of agricultural production (MOAG 2006), in comparison with around $32 \%$ of the production value in the EU (OECD 2006). The vehicle of support also differs between Israel and the EU: whereas most of the agricultural support in the EU is provided through income payments to farmers, in Israel it is mainly provided through partial coverage of investments in farms (Fig. 3) and by charging lower prices for irrigation water than the price charged for water for domestic use. Both mechanisms can lead to negative environmental impacts, such as excessive use of scarce water resources or construction of greenhouses and other agricultural buildings in the otherwise open space. The limited income payment programs are not anchored in laws or regulations, but are rather negotiated annually between farmers' representatives and the authorities.

Policies that focus on mitigating the negative impacts of farming on the environment are at the initial stages of development in Israel, and comprise mandatory regulations, economic instruments and advisory measures. Around 30 environmental laws and regulations relate to 


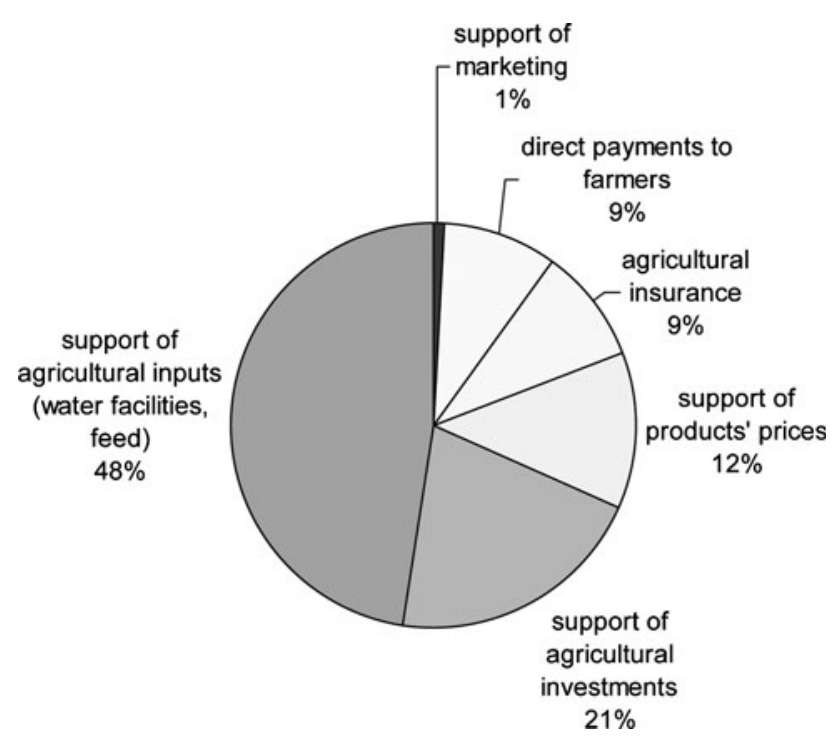

Fig. 3 The vehicles of public support for agriculture in Israel. Source: Adapted from MOAG (2006)

farming activities (MOEP 2007), covering issues such as the prevention of hazards (noise, foul smells, water and air pollution); use of dangerous materials (fertilizers and pesticides); mitigation of waste caused by crops and livestock cultivation; etc.

A number of Israeli Ministry of Agriculture financial support programs have shown positive environmental impact (Table 2), although none bear the explicit title of "agri-environmental scheme", and the overall environmental impact of the programs is not considered. In general, these programs are well-accepted by the Israeli farmers. The program for introducing environmental protection facilities into dairy farms was implemented in 1999-2006. By 2006, 46\% of all Israeli dairy farms fulfilled the required investments in waste treatment facilities and other measures for preventing pollution from farm waste (IDB 2006). As for the support program for investment in water systems and in low-irrigated plantationsaccording to the official in charge of it, it proved to be highly popular among farmers throughout all its years of operation, and the number of applications always matched or exceeded the available budget (E. Hadas, the investments administration, Israeli Ministry of Agriculture, oral communication, 6 January 2010). The support for wheat farming is provided to all farmers in the southern, arid region of Israel, and is not managed through individual contracts with farmers; therefore the rate of acceptance by farmers is difficult to determine.

Other changes in cultivation, to more environmentallybeneficial crops and/or methods (e.g., lower use of chemicals, transition to organic farming etc.) are not financially supported in Israel at the moment, but are promoted through the agricultural extension service and the governmental agricultural research organization (S. Israel, Manager of the Department for Plant Protection, the Israeli agricultural extension service, oral communication, 12 November 2008). Detailed data regarding the success of these advisory measures is not available.

An important agri-environmental goal that the current instruments do not address is promoting the positive influences of agriculture on the environment (i.e., creation of aesthetic landscape, protecting biodiversity, etc.). The only program that currently relates to this aim involves direct payments to wheat farmers in southern areas, which also promotes aesthetic amenities. However, other environmental impacts of wheat cultivation are not tackled within the framework of this program, and its overall environmental impact is debatable.

All of the above suggest that the current mechanisms used in Israel to address the agri-environment are only partly effective. Mandatory regulations seem to be effective in protecting open spaces; however, to be less effective in preventing abandonment of fields. The current economic instruments have low ecological effectiveness, as they may encourage methods of cultivation that are not environmentally beneficial; the programs that have a positive environmental impact are not explicitly considered "agrienvironmental schemes" and their overall environmental effect may not be beneficial. The Israeli Ministry of Agriculture invests effort into the promotion of environmentally sustainable cultivation through research and extension, however the effectiveness of this effort has not been systematically studied. One may presume that without extra incentive, the farmers' motivation to change their cultivation is not high. The positive environmental effects of agriculture are barely remunerated, and given the trend of fields abandonment, may not be achieved in the long run without suitable remuneration. Expanding the use of economic instruments when addressing the agri-environment holds potential for reaching more effective ecological results.

Expanding the use of economic agri-environmental instruments in Israel is feasible thanks to its developed economy, which allows allocating public funds for promoting the agri-environment, and the general acceptance of this policy by the public at large, as demonstrated by the WTP surveys presented above.

The farmers' acceptance of economic agri-environmental instruments can be judged based on the good acceptance rate of the current programs, as well as on the answers of the farmers interviewed within the pilot project conducted at the Megido Regional Council. The latter form a complex picture: on the one hand, 18 of the 21 farmers who were interviewed stated that the government should provide more assistance to farmers. However, 6 of them objected to the government's financial support of farmers 
Table 2 Israeli agricultural support programs with positive environmental impact, 2005

\begin{tabular}{llll}
\hline Program & $\begin{array}{c}\% \text { of total agricultural } \\
\text { support, 2005 }\end{array}$ & Type of support & Environmental implication \\
\hline The reform in the dairy branch & 12.6 & $\begin{array}{c}\text { Support for investment in waste treatment } \\
\text { facilities in dairy farms } \\
\text { Support for investment in water systems, } \\
\text { and low-irrigated plantation (olives) } \\
\text { Direct payments to wheat cultivators }\end{array}$ & $\begin{array}{c}\text { Cultivation of wheat fields as a means } \\
\text { of protecting open spaces }\end{array}$ \\
$\begin{array}{l}\text { Investments improving the } \\
\text { efficiency of water use }\end{array}$ & 1.7 & 9 & $\begin{array}{c}\text { Direct payments to wheat } \\
\text { farmers in southern areas }\end{array}$ \\
\begin{tabular}{l} 
Total \\
\hline
\end{tabular} & 23.3 & & \\
\hline
\end{tabular}

Inclusion of a program in this table does not signify that its overall environmental impact is positive, only that it bears some positive environmental impact. For example, direct payment to wheat farmers in southern Israel contribute to the protection of open spaces, however it may also lead to other, less desirable environmental effects. Source: Authors' analysis based on data in MOAG 2006

(3 expressed both support and opposition to the policy), and 11 preferred that the government would assist the farmers in alternative ways (i.e., grant a discount on prices of irrigation water, construct agricultural infrastructure, etc.). Six farmers preferred the use of advisory measures to economic instruments, and 2 farmers preferred stricter use of mandatory regulations. Only 2 farmers regarded the implementation of economic instruments for addressing the agri-environment positively, whereas 4 farmers stated that promoting the agri-environment is not a good goal for public funds (promoting intensive cultivation was considered a better goal).

The institutional feasibility of applying economic agrienvironmental instruments in Israel is limited by the fact that farmers in this country currently receive very limited payments. The development of a model for delivering funds to farmers for promoting the Israeli agri-environment is advisable.

\section{Agri-Environmental Payment Schemes and Their Potential in Israel}

Experience gained in other countries may serve as a reference when developing economic agri-environmental measures in Israel. The EU's agri-environmental policy was initiated by some member states as voluntary programs from the early 1980s. The policy was made compulsory in 1992, with the integration of agri-environmental measures as part of the "second pillar" of the Common Agricultural Policy. Economic instruments play a major role within the EU's agri-environmental policy, with subsidies/support schemes comprising a central measure (Bräuer and others 2006). We will therefore focus on agri-environmental schemes, although other economic instruments are just as relevant.

Currently, the agri-environmental schemes are based on Council Regulation (EC) No. 1698/2005, and are mutually financed by the EU and the individual member states, which are responsible for their design and implementation within rural development programs. Within the framework of an agri-environmental scheme, farmers are usually requested to perform certain actions that are considered environmentally desirable, or refrain from carrying out others. In return, they receive a payment that is calculated on the basis of the estimated average opportunity costs, and is usually uniform for all the participants in the program. The farmers' participation is voluntary, and is organized through contracts between individual farmers and the authorities. Participation in the program is rendered attractive by remuneration that exceeds the calculated opportunity costs (Marggraf 2000). The schemes aim to achieve ecological results that surpass "good farming practices", as defined by the member states.

The conventional agri-environmental schemes, as practiced in the EU for about two decades, are centrally-planned, meaning that their ecological and economic parameters are set by the authorities. Although the ecological and economical effectiveness of these conventional agri-environmental schemes was contested (Kleijn and others 2006; Kleijn and Sutherland 2003; Marggraf 2003; von Haaren and Bathke 2008; von Haaren and Bills 2007) it seems reasonable to argue that they can contribute to supporting the environmental benefits of agriculture in Israel, in addition to the instruments currently in use.

The feasibility of implementing agri-environmental payment schemes in Israel is, however, complex. Some institutional aspects support their implementation; for example, a definition of "good agricultural practice" exists within the framework of some 30 environmental laws and regulations that relate to farming activities, as mentioned above (MOEP 2007). However, other institutional aspects restrict the implementation of agri-environmental payment schemes. These emerge mainly from the prevailing vehicle of support for farmers. Although in essence agri-environmental payment schemes are not subsidies or income 
transfer, but rather payment for an environmental service, the political acceptability of such measures may be greater in an environment where there is a tradition of agricultural subsidies. In Israel, on the contrary, income payments to farmers are limited in scope, and are not well established politically. It may be difficult to establish a system of income payments for promoting agri-environmental services alone.

Another limitation to adopting agri-environmental payment schemes in Israel is the prevailing attitude of policy makers, who oppose subsidies and promote market orientation in the agricultural sector. This attitude is evident in the drastic cutbacks in public support for farmers by almost $50 \%$ in the last decade (Natan 2007). This means that although the Israeli public at large may support payments for agri-environmental services (as demonstrated by WTP surveys) the delivery of funds according to a centrally planned, non-competitive model may not be accepted by the public's representatives. Consequently, a market-based model that emphasizes competition between farmers is called for.

\section{Market-Based Instruments in Agri-Environmental Schemes}

The centrally-planned agri-environmental schemes were criticized for their low level of effectiveness in achieving ecological aims, particularly with regard to the improvement of biodiversity (Kleijn and others 2006; Kleijn and Sutherland 2003). They were also criticized for their unsatisfactory cost-effectiveness, as their use of uniform premiums leads to both over- and under-compensation of farmers, due to different farm production costs and site conditions (Marggraf 2003; von Haaren and Bathke 2008; von Haaren and Bills 2007).

The integration of market economy components into the schemes has recently been discussed with the aim of improving them. These enhanced schemes have been partially incorporated into the policy or implemented within the framework of pilot projects (Gerowitt and others 2003a, b; Hampicke 2006). Markets for agri-environmental services are not as easy to establish as markets for private goods, as most of the agri-environmental services are public goods. Notwithstanding, it is possible to introduce some market components into the design of agri-environmental schemes (Gerowitt and others 2003a, b; Hampicke 2006), such as: (a) Result-oriented remuneration (Briemle 2000; Matzdorf 2004; Wittig and others 2006); (b) The use of conservation auctions (Groth 2007; Latacz-Lohmann and Van der Hamsvoort 1997); (c) Public participation in defining the demand for environmental services (Müller and others 2002); and (d) Local organization (Bauer 2006;
Eggers 2005). These instruments are detailed in brief below, and the possibility of their implementation in Israel is subsequently discussed.

\section{Result-Oriented Remuneration}

The consumers of agri-environmental services are interested in the ecological results, and not only in the activities carried out by the farmers (Gerowitt and others 2003a, b; Hampicke 2006). Therefore, remuneration should be given for the actual effects of agriculture on the environment, and not merely for activities considered appropriate, as is the case in the conventional action-oriented agri-environmental schemes. For example, in the case of livestock farmers, the action-oriented programs may pay them to graze their herds in order to sustain grassland biodiversity. On the other hand, a result-oriented scheme would pay the farmers for the actual presence of flora and fauna in their field, regardless of how it came into existence.

In addition to improving the environmental effectiveness of the schemes, result-orientation also supports farmers' environmental innovation, as they are not provided with guidelines for the production of the environmental service, and can develop the conservation protocols individually (Latacz-Lohmann and Schilizzi 2005). Resultorientation may also promote the farmers' interest in environmental problems, as well as cooperation between farmers in the quest for their solution (Matzdorf 2004). The absence of restrictions on farmers' actions may promote their acceptance of the schemes (Klimek and others 2008).

The feasibility of a result-oriented approach is conditional on two central factors (Bertke and others 2005; Gerowitt and others 2003a, b; Matzdorf 2004; Wittig and others 2006): that the results are defined in a clearly measurable way, so that identification and monitoring may be easily performed; and that the results are associated with a particular field and producer, to enable the farmer to prove that he/she supplied it (Bertke and others 2005; Briemle 2000; Wittig and others 2006). Usually, a resultoriented project employs a set of indicators as proof of environmental result attainment. Weed species on arable land, or herb species in grassland, may be a good indicator of the attainment of agricultural biodiversity (Bertke and others 2005; Briemle 1999; Matzdorf 2004; Wittig and others 2006). Other indicators that have been used in resultoriented schemes include meadow bird clutches or carnivore offspring (Musters and others 2000; Zabel and Holm-Mueller 2008).

Result-oriented agri-environmental schemes for the promotion of plant diversity in grasslands are currently implemented within the framework of agri-environmental schemes in some federal states in Germany and in Switzerland (Oppermann and Gujer 2003; Schwarz and 
others 2008; Wittig and others 2006), as well as within the Bush Tender program in Australia (DSE 2008).

\section{Conservation Auctions}

Auctions, practiced as public tenders, can serve as an appropriate instrument for the efficient allocation of public money in exchange for the provision of environmental services, in the same way as they are used in the provision of other public goods by private firms (Stoneham and others 2003). Policymakers lack information about the production conditions of the single farmer. Auctions provide a mechanism for flexible allocation of public money based on the farmers' individual production costs (Ferraro 2008; Latacz-Lohmann and Van der Hamsvoort 1997; Mello and others 1998). In an agri-environmental scheme that employs auctions, each farmer calculates the production costs of the agri-environmental service individually, and then submits a bid in response to a public tender. The farmers offering the lowest bids will be accepted into the program, and the payments will be made according to their bids.

Conservation auctions have been implemented in some specific programs in the USA and in Australia, as well as in some experimental projects in Europe and elsewhere (CJC Consultants 2004; Jack and others 2008; Kirwan and others 2005; Klimek and others 2008; Stoneham and others 2003; von Haaren and Bathke 2008). Article 39 of the Council Regulation (EC) No. 1698/2005 recommends the use of auctions for agri-environmental services, provided they increase the efficiency of the scheme.

\section{Participatory Approach}

The price, as an indicator of value and scarcity, is an important principle of the market system. Principally, the price of specific agri-environmental goods should be determined as an equilibrium between their value to the public and their production costs, and not solely according to the production costs, as is usually the case in the conventional agri-environmental schemes (Gerowitt and others $2003 a, b)$. Within the framework of a market-oriented agrienvironmental scheme, the upper limit of the sum of the remuneration given to the farmers should be determined by the value of the agri-environmental service they provide to the public (as the production costs are the lower limit). In order to determine this value, it is necessary to implement a participatory approach in setting the economic parameters of the scheme, for example, using sophisticated assessment methods to determine the population's willingness to pay for agri-environmental services. Such surveys can constitute a participatory mechanism, as long as their results are integrated into the policy design. Another way of considering the public's preferences is engaging a commission of relevant local stakeholders to represent the public demand and to decide on the detailed design of the scheme (Bertke and others 2005; Gerowitt and others 2003a, b; Musgrave 1956/57, Rueffer 2007).

In addition to expressing the actual demand for agrienvironmental services, a participatory approach in agrienvironmental policies helps mediate interests between groups, thus ensuring that the aims of the policy are accepted by many. It also improves the amount and quality of information that the decisions are based upon by benefiting from the knowledge of local laypersons (Prager and Freese 2009). Public participation allows policy makers to gain insight into the social network that will be required to implement the policy, and thus understand the probability of their acceptance (Newig and others 2005).

Public participation in the design of environmental policy has been promoted by Agenda 21 and by the Convention on Biological Diversity. In the EU, public participation constitutes the core concept of the Aarhus Convention and its resulting European legislation. EU member states are now required to integrate citizens' participation into various policy areas; examples include "the leader concept" in EC Council Regulation No. 1698/2005 and the Water Framework Directive 2000/60/EC.

\section{Local Organization}

Natural conditions and land use types differ widely between regions. So do public preferences; hence the willingness to pay for agri-environmental services (Marggraf 2000). This calls for the local organization of agri-environmental schemes, in line with the European Union's principle of subsidiarity (Groth 2007; Prager and Freese 2009).

Although local organization is not strictly a marketbased measure, some market-based instruments are easier to operate, and may yield more accurate results when practiced on a local basis. It is easier to conduct willingness-to-pay surveys on a small scale, and their results will better match the particular ecological features of the area. A set of ecological indicators for the practice of resultorientation can be more accurately developed, given a specific area with its particular ecological characteristics. Some evaluations of agri-environmental measures demonstrate the good results of local and site specific measures, in contrast to more global ones (von Haaren and Bathke 2008).

Although these market-based instruments have been advocated by European academics for almost a decade, they are actually integrated into policy only in a number of countries or regions. Indeed, these instruments are not without faults. Result-orientation faces the problems of 
unobservability of some environmental outcomes and unclear landholder responsibility, and is therefore practicable for only a number of environmental benefits, such as plant biodiversity (Klimek and others 2008; LataczLohmann and Schilizzi 2005). It also exposes the farmers to risks, as the effects of management changes on the environment are not always clear, and the impact of unexpected climate events cannot be predicted. In fact, result-orientation shifts the risk of lower environmental effectiveness away from the government and onto the farmers, and may reduce the level of acceptance of the scheme by risk averse farmers (Latacz-Lohmann and Schilizzi 2005). In addition, it may be maintained that ensuring a positive environmental outcome should include overall environmental assessment of the measure, not only measurement of a specific result pursued. There are cases in which the specified environmental goal is achieved, but at a cost of negative environmental impact (this is an overall problem of any measure aiming at specific problems, not only result oriented instruments).

A conservation auction is a complex incentive mechanism with a higher risk of failure in comparison to a flatrate scheme (Latacz-Lohmann and Schilizzi 2005). The use of auctions is expected to be more complex to administer, entail higher transaction costs to farmers and the administration and require higher human capital to design and implement (Ferraro 2008; Latacz-Lohmann and Van der Hamsvoort 1998; Lowell and others 2007). Auctions are probably worth their administrative costs only when there is a high degree of information asymmetry, heterogeneity of costs among farmers, and a large pool of bidders to induce competitive pressures (Ferraro 2008; LataczLohmann and Van der Hamsvoort 1998); this is often not the case in targeted sites, where high environmental assets are concentrated in a small area (Stoneham and others 2003). The use of auctions does not prevent the farmers from getting payments that exceed their reservation rents (Kirwan and others 2005). When conservation auctions are issued repeatedly, their contribution to economic efficiency diminishes, as the winning price level reaches that of the price the administration was willing to pay under a fixed-rate scheme (Lowell and others 2007; Schilizzi and Latacz-Lohmann 2007). Auctions also run the risk of being perceived as unfair by farmers (Latacz-Lohmann and Schilizzi 2005).

As for public participation-a number of technical problems are involved in the implementation of this principle. Often, the authorities do not know who to involve, when and for which purpose. Established organizations often oppose participatory approaches, as they may bring about a reallocation of power, budgets or other limited resources (Prager and Freese 2009). Participation is associated with additional efforts and costs on the part of the authorities, and is exposed to misuse by decision makers with hidden agendas: some may choose to draw out a public participation process in order to delay the implementation of challenging policies; others may utilize public participation forums as arenas for displaying their political power, rather than focusing on the issue at hand. Consequently, a participatory process might hinder quick and effective implementation of a needed policy (Newig and others 2005). In addition, relying on a public participation mechanism subjects the valuation of experts to that of the public; the ecological service in question must benefit from broad societal demand, otherwise its conservation would not be supported, even if conservation experts believe it is of high value (Klimek and others 2008).

As for local organization, some centralized administrative systems do not support the implementation of this principle, as will be demonstrated by the Israeli case study.

\section{The Potential of Market-Based Agri-Environmental Instruments in Israel}

The potential of the market-oriented agri-environmental instruments in Israel was studied within the framework of the pilot project carried out at Megido Regional Council. We present the institutional feasibility of implementing each instrument, its acceptance by the project's stakeholders (farmers, and policy makers as representatives of the larger public), and its effectiveness (ecological and/or economical). We will mostly consider the perceived effectiveness of the instruments (as perceived by our interviewees), since exploring the actual ecological and economic effectiveness was beyond the scope of this study (some aspects of the actual effectiveness are planned to be studied in a follow up project). A summary of the arguments in favor and against using market-oriented instruments, as raised by our interviewees, is presented in Table 3.

\section{Result-Oriented Remuneration}

Using a result-oriented approach is institutionally feasible in Israel, as payments for farmers within the existing programs are usually conditional on performance. Remuneration for investments in farms (a main instrument of farmers' support in Israel) is not paid before the farmer has proven that he/she has actually made the investments. However, public support is not conditional on improved agricultural achievements (e.g., better yields), and in this sense may not be considered result-oriented. Similarly, in the environmental policy, polluters are sometimes 
Table 3 Arguments in favor and against using market-oriented instruments, as expressed by the project's stakeholders

\begin{tabular}{|c|c|c|c|c|c|}
\hline Instrument & $\begin{array}{l}\text { Type of } \\
\text { argument }\end{array}$ & Arguments & Farmers & $\begin{array}{l}\text { Policy } \\
\text { makers }\end{array}$ & Total \\
\hline \multirow[t]{6}{*}{$\begin{array}{l}\text { Result } \\
\text { orientation }\end{array}$} & \multirow[t]{3}{*}{ In favor } & $\begin{array}{l}\text { A necessary instrument of enforcement, to ensure the farmers will fulfill their } \\
\text { obligations within the project }\end{array}$ & 4 & 6 & 10 \\
\hline & & $\begin{array}{l}\text { Conditioning the payment on performance is an established institutional regulation, the } \\
\text { authorities may not be able to transfer payments to farmers without proof of } \\
\text { performance }\end{array}$ & - & 1 & 1 \\
\hline & & Environmental effectiveness & - & 1 & 1 \\
\hline & \multirow[t]{3}{*}{ Against } & Some farmers lack the initial funds for starting the project & 3 & - & 3 \\
\hline & & $\begin{array}{l}\text { The government cannot be trusted to pay after the farmer has already produced the } \\
\text { results }\end{array}$ & 2 & 1 & 3 \\
\hline & & The farmer may encounter unexpected difficulties in producing the desired results & - & 2 & 2 \\
\hline \multirow[t]{6}{*}{$\begin{array}{l}\text { Conservation } \\
\text { auction }\end{array}$} & \multirow[t]{3}{*}{ In favor } & $\begin{array}{l}\text { Allowing policy makers to objectively select who will participate in the project and how } \\
\text { much money they will be paid }\end{array}$ & - & 4 & 4 \\
\hline & & Matching the level of payment to the needs of the farmers & 1 & 2 & 3 \\
\hline & & $\begin{array}{l}\text { Obligating the farmers to make an effort, so that the farmers who will ultimately take } \\
\text { part in the project will be those who are willing to invest serious effort }\end{array}$ & 1 & 1 & 2 \\
\hline & \multirow[t]{3}{*}{ Against } & $\begin{array}{l}\text { Most of the farmers do not know how to calculate their production costs, and are } \\
\text { incapable of submitting reliable bids }\end{array}$ & 5 & 6 & 11 \\
\hline & & $\begin{array}{l}\text { Large and successful farmers can compete better because they can allow themselves to } \\
\text { earn less; smaller farmers will find it difficult to compete }\end{array}$ & 3 & 4 & 7 \\
\hline & & $\begin{array}{l}\text { An auction transmits a message that the authorities do not really want to support the } \\
\text { farmers }\end{array}$ & 4 & 1 & 5 \\
\hline \multirow{6}{*}{$\begin{array}{l}\text { Public } \\
\text { participation }\end{array}$} & \multirow[t]{3}{*}{ In favor } & Expanding the acceptance of policy & 1 & 4 & 5 \\
\hline & & Getting ideas that can improve the policy & 1 & 3 & 4 \\
\hline & & Improving the relations between farmers and the public at large & 1 & 2 & 3 \\
\hline & \multirow[t]{3}{*}{ Against } & Introducing uncertainty into the policy & 0 & 2 & 2 \\
\hline & & Bias due to particular interests & 0 & 2 & 2 \\
\hline & & Difficulty in resolving disagreements between the public and the policy makers & 0 & 2 & 2 \\
\hline \multirow{6}{*}{$\begin{array}{l}\text { Local } \\
\text { organization }^{\mathrm{a}}\end{array}$} & \multirow{3}{*}{ In favor } & Adaptation to local conditions and needs & - & 4 & 4 \\
\hline & & Establishing local partnerships & - & 3 & 3 \\
\hline & & Enhancing implementation efficiency & - & 1 & 1 \\
\hline & \multirow[t]{3}{*}{ Against } & Local authorities cannot operate without national support & - & 2 & 2 \\
\hline & & The local administration may interfere too much in individual farmers' operations & - & 1 & 1 \\
\hline & & Creating excessive bureaucracy & - & 1 & 1 \\
\hline
\end{tabular}

The number indicates the number of interviewees who voiced the argument. Some interviewees voiced more than one argument, whereas others did not voice any. The 3 most often voiced arguments for each category are presented

${ }^{a}$ Only policy makers were asked about this instrument

encouraged to mitigate their nuisance by partial coverage of investments in a relevant technology; however, payment is not conditional on actual environmental results (for example, a lower level of pollution).

In line with the institutional framework, the prominent attitude towards result-orientation among the policy makers in the survey was supportive (supported by 6 of 9 policy makers); in contrast, only 4 farmers were unequivocally in favor of this approach. It is worth noting that many interviewees ( 3 policy makers and 6 farmers) perceived resultorientation as a means of enforcement, ensuring that the farmers do what they have undertaken to do before getting paid. In this sense, it may be considered as improving the economic effectiveness of the scheme (public money will only be given to farmers who perform the required tasks). Although mostly perceived as a merit, one policy maker stated that when associated with enforcement, result-orientation may be rejected by the farmers, as they might deduce that the government does not trust the farmers to fulfill their commitments. Only one interviewee in our survey (the representative of the forestry authority) understood the approach as an instrument for achieving 
ecological effectiveness (i.e., paying for actual ecological results).

Objections to the approach were raised mainly by the farmers. Three farmers said that the funds for starting the environmental project were not always available to farmers, and therefore they should receive public assistance in the early stages of the project. Two farmers (and one policy maker) said that farmers do not trust the government to transfer payment after they had already fulfilled their environmental commitments. One farmer (and one policy maker) stated that environmental results take a long time to achieve, and the farmers cannot wait that long for payments.

The questions of measuring the results and the responsibility for the risk of failure to achieve them, as raised in the literature dealing with result-orientation (Latacz-Lohmann and Schilizzi 2005) were seldom raised in our survey (one policy maker related to the first, and two to the second). When provoked with the question of the risk imposed on farmers by the approach, six policy makers and one farmer rejected the idea, saying that they trusted the agricultural experts that provide professional support during the project to design the cultivation protocol in a manner ensuring that the farmers will deliver the requested results. Only two policy makers acknowledged that the farmers may fail to deliver the required results, due to reasons that are not within their control, and maintained that in this case - the farmers should be remunerated for their efforts regardless.

Did result-orientation improve the ecological effectiveness of the project? A major environmental problem that the project was meant to mitigate was soil erosion. As this goal cannot be associated with a specific producer or farm, and is difficult to measure, it cannot be addressed via a strict result-oriented approach. Another environmental service that was promoted within the project involved creating aesthetic landscapes, and to this end, a number of guidelines were established regarding the design of the olive groves. This environmental service can be delivered using a result-oriented approach, as the groves' association with a single farm and grower cannot be questionable, and the design and composition of the desirable grove can be determined in a measurable way (e.g., specifying the interval between trees, their height, etc.). However, such a definition of the landscape qualities of the grove does not leave the farmer much room for innovation, which is one of the goals of result-orientation. Regarding protection of biodiversity - as the impact of the groves on biodiversity required further study, the project's managers preferred not to condition the payment on results in this aspect. In sum, result-orientation improved the effectiveness of the project only regarding landscape aesthetics.

\section{Conservation Auctions}

Tenders have a long tradition in the Israeli governance system, due to many years of tendering obligation instituted within the framework of the Municipalities Ordinance, governmental regulations (Shalev 1989), and finally, by the "Law of Obligatory Tendering-1992". Consequently, it is institutionally feasible to announce tenders for the supply of agri-environmental services as well. The innovation of the pilot project at the Megido Regional Council lies in basing payment to farmers for agri-environmental benefits on the established tendering obligation. Tenders are not usually issued in the agricultural sector, where farmers are given assistance based on flat-rates that are set by the government, and according to a "first-comes-first-served" principle. Our interviews revealed that the only semi-agricultural organization that often announces tenders is the forestry authority, when it allocates cultivation and tree-clearing rights in forests. Issuing a tender to buy agri-environmental benefits encapsulates a change in approach-considering these benefits as public services, and purchasing them from farmers using the institutional instrument that is legally suitable for such a purchase. In the pilot project, the farmers were asked to compete on the share of public remuneration for their investment in planting the olive groves.

Although more than half of the policy makers involved in the project supported the use of auctions ( 5 of 9 policy makers), 16 of the 21 interviewed farmers opposed it. The most important argument in favour of using an auction, raised by 4 policy makers, was that an auction is a necessary instrument for making public decisions fairly and transparently; it allows the authorities to objectively select the participants in the project, and the level of payment that they will receive.

Many more arguments were raised against the conservation auction than in favor of it (5 in favor, 12 against). The most prominent argument against the auction was that the farmers do not know their production cost, and therefore cannot submit realistic bids; this was suspected of leading to detrimental social and environmental outcomes: If bids that are unrealistically low are awarded in the auction, the farmers who had submitted them would either not be able to fulfill their commitments at the expense of the environment, or fulfill them at a risk to their livelihood.

Other important arguments against the auction were that it favors large and successful farmers over smaller ones; and that it transmits a message suggesting that the authorities do not truly want to support the farmers. It seems that in the current atmosphere in Israel, where agricultural subsidies were drastically cut back, farmers yearn for public acknowledgment of their service to society. When the authorities set the level of remuneration it was as if they were determining the value of 
agri-environmental services; on the other hand, a conservation auction might make it appear as though the farmers are bargaining for public charity - an image that the Israeli farmers would be reluctant to be associated with.

It is difficult to judge whether the auction in our project improved its economical effectiveness, since there was no compatible centrally-planned scheme to compare it to. However, it should be noted that the auction was not perceived by our interviewees as improving the project's effectiveness. Indeed, our interviewees did not refer to the auction from the perspectives of cost-effectiveness or saving public funds, and when provoked with this ideathey rejected it as unimportant or misleading. For example, the Regional Council's architect mentioned that the obligation to issue tenders and select contractors according to their bids often lowers the quality of the service delivered to the public. In the context of the pilot project, she raised the concern that farmers might submit bids that are too low, wouldn't deliver the environmental goods, and "you end up wasting public funds".

Despite its not being well accepted by the project's stakeholders, the conservation auction was implemented in the project, since the tendering method is integrated into the regulative system in Israel, and was considered by the stakeholders to be the only legitimate way for local authorities to transfer money to private entities (farmers).

\section{Participatory Approach}

Public participation in policy decision making in Israel today is realized mainly within the framework of spatial planning. According to the "Law of Planning and Construction-1965" spatial plans that receive preliminary approval by the planning authorities must be open to public scrutiny, and those who feel harmed by them may file an objection. In addition to this formal mechanism, a more informal approach has been implemented by the planning authorities in recent years, and many plans are accompanied by a process of public hearings, preference surveys, consultations with focus groups, etc. (Kaplan 2004).

Public participation has thus far been limited to the regulatory system, and is seldom practiced by the initiatory system (Soen 1997). The latter includes the ministries in charge of development (Housing, Trade and Industry, Agriculture) and other governmental and semi-governmental bodies that initiate and implement development projects. Within the agricultural sector, farmers' organizations are active in many decision making bodies, however the public at large is less involved in this process. Providing this background, it may be said that a participatory approach in the design of agri-environmental scheme is more feasible when the public intended to be involved comprises the farmers, and less so when the public at large is considered.

The policy makers in the survey were generally supportive of the idea of public participation ( 7 of 9 interviewees); however, the approach was much less popular among the farmers, and only one of them was willing to unreservedly consider it. The supporting interviewees regarded public participation as a way of increasing the acceptance of the policy, improving it and strengthening the relations between the farming and non-farming population in the area. The perceived disadvantages of the approach were: introducing uncertainty into policy; the possibility of bias in the policy according to particular interests; and the difficulty involved in case of disagreements between the public's attitude and that of policy makers.

Notwithstanding their general support of public participation, 6 policy makers raised a number of issues concerning this approach, such as: in which questions to involve the public; how to manage the process; and whom to include in it. The last point was discussed at lengthshould the participating public include the local or broader public; whether to also include the people who have financial interests in the project; and how to avoid involving only those who have clear political agendas. The question whether to involve the farmers or the public at large was a central one. Three policy makers and 3 farmers said that only the farmers should be involved in the process; they were concerned that the public at large did not have enough agricultural knowledge to contribute to the process.

Although not stated openly, it may be assumed that the perception of the general relations between farmers and non-farmers influenced the farmers' attitude toward the involvement of the public in the design of the scheme. Thirteen farmers in our survey (and 5 policy makers) claimed that the general public was hostile to the farmers in questions relating to the use of natural resources and public budgets. Five farmers (and 2 policy makers) claimed that the public was unwilling to financially support farming; 5 policy makers and one farmer stated that even those sectors of the Israeli public who appreciate the environmental services of agriculture perceive them as self evident and are unaware of the investment needed to sustain them. Given this perception of the public attitude, it is of little wonder that the majority of the interviewed farmers considered trying to involve the public at large in designing an agrienvironmental payment scheme as an ineffective approach.

A participatory approach can potentially improve the economical effectiveness of the scheme by setting its economic parameters in relation to the public's demand and willingness-to-pay. Due to the pilot project's budgetary constraints, it was impossible to conduct a WTP survey in 
order to take into account the public's preferences in designing the scheme. However, the project's stakeholders were consulted on the feasibility and benefits of implementing this instrument. Although acknowledging the possibilities of translating public preferences into economic values, only 2 policy makers (and none of the farmers) supported the idea of setting the budget according to the preferences of the general public. The objecting interviewees argued that the public's stated willingness-topay is not based on real economic considerations, is unstable, and is sometimes biased by particular interests. A participatory approach was therefore not perceived as contributing to the economical effectiveness of the scheme.

\section{Local Organization}

When examining the institutional feasibility of organizing agri-environmental schemes in Israel on a local basis, one should note that the governance system in Israel is rather centralized. For example, most of the Ministry of Agriculture's decisions are made on the national level, despite the fact that the country is divided into 5 agricultural districts. Although the districts manage independent research and extension services, they do not have independent budgets, and they can only submit recommendations to the central administration on issues involving the allocation of financial support to farmers. Local organization exists within the realm of open-space management, for example, in the form of watershed administrations. These are often voluntary organizations that unite a number of municipalities in order to manage a river basin and the open spaces associated with it. However, these are also mainly advisory boards, with no statutory power or budgetary authority.

As for local governance, in the urban sector, governance is administered either at the national level or at the municipal level. In the rural sector, there is an intermediate level of governance, since villages are grouped together and governed by one "regional council". In total, there are 54 regional councils in Israel, ranging broadly in size, from 3 to $4,000 \mathrm{sq} \mathrm{km}$, and from 3 to 63 villages (ICBS 2005). The division of authority between the villages and their respective regional councils is not clearly defined in Israeli legislation (Applebaum 2002). In the past, the regional councils had very little effective governance capabilities, and each village managed its educational system, environmental services, etc. independently. However, since the 1990s, following an economic crisis in the rural sector that made it impossible for many villages to continue providing municipal services independently, the regional councils assumed more and more municipal roles. At present, most of the regional councils provide educational and cultural services, some environmental services and some services to the farmers (Applebaum 2002). When exploring the institutional feasibility of establishing an agri-environmental policy in Israel at the local level, the regional councils seem to be the obvious policy agent (and indeed were advocated as such by 3 interviewees).

Local organization was considered too broad a policy issue to be discussed with farmers, and therefore only the policy makers were asked about this instrument. In general, our interviewees strongly supported a local organization approach in agri-environmental policy (8 of 9 interviews). The interviewees perceived the local organization approach as improving the effectiveness of the scheme, both economically and ecologically, by facilitating implementation, improving adaptation to local conditions and needs, and establishing local partnerships. Two interviewees advocated a mixed approach, such as setting the policy principles at the national level, but designing the schemes, or managing them, at the local level.

However, in practice, local organization was only partially implemented in the pilot project. Indeed, the project was executed on the local scale; however, national policy makers followed the process throughout its stages, within the framework of the steering committee's activities. In some cases (e.g., the question of flat-rate versus auction design) the national policy makers' attitude was considered as having veto power, which effectively determined the decisions made.

An examination of the criteria of choice between measures, as suggested in our conceptual framework, reveals that the only market-based instrument that was considered by our interviewees as improving the effectiveness of the project was local organization. Our interviewees doubted that a conservation auction or a participatory approach may enhance the economic effectiveness of the project. Resultorientation, considered as a means of enforcement, was perceived as improving the effectiveness of the scheme; however, its influence on ecological results was barely considered by the interviewees.

As for feasibility of implementation-result-orientation and conservation auction are institutionally feasible within the Israeli system, and indeed were integrated into the pilot project (at least partially), unlike the participatory approach and local organization, that are less in line with the Israeli institutional infrastructure. As for acceptancethere seemed to be strong disagreement between the policy makers in our study (as representatives of the general public's view) and the farmers. The policy makers considered all the market-based instruments appropriate, whereas the farmers rejected the instruments they were presented with. This raises the question of whose acceptance has higher priority in the design and success of an agri-environmental scheme. 


\section{Conclusion}

This paper discussed the pathway of choosing policy measures to address the agri-environment. We suggested a broad conceptual framework, examining the general policy measures that can be used to tackle the agri-environment (mandatory regulations; economic instruments; advisory measures); then focusing on the economic instruments, and specifically on market-based ones. We suggested that there are two criteria of choice between the measures and instruments: the instrument's contribution to enhancing the effectiveness of the policy (whether economical or ecological); and the feasibility of its implementation.

We followed this conceptual framework to explore the development of agri-environmental policy instruments in Israel. At the moment, Israel is implementing a combination of mandatory regulations, economic instruments and advisory measures in its handling of the agri-environment. However, economic instruments are under-represented (in comparison with other developed economies, especially the EU) and may contribute to more effective environmental impact. The feasibility of introducing more economic instruments into the agri-environmental policy in Israel is, however, complex - on the one hand, they are accepted by the public (as demonstrated in WTP surveys); but on the other hand-payment schemes do not suit the institutional infrastructure in which subsidies to farmers are not an established practice.

Following further discussion of the current political atmosphere, in which farmers are asked to be more marketoriented, we concluded that market-based instruments have a higher feasibility of implementation in Israel than centrally-planned schemes. Within the framework of a pilot project, we implemented four market-based instruments that are being utilized in other countries, and studied the feasibility of their implementation, and their perceived impact on the policy's effectiveness. We found that the scheme's stakeholders do not regard market-based instruments as tools that may improve the effectiveness of the scheme, either economically or ecologically. It seems that the question of effectiveness was hardly on the minds of the policy makers and farmers involved in our project, and other arguments should have been used to convince them of the merits of the market-based instruments.

As for feasibility-the main conclusion is that the instruments that are in line with the existing institutional framework are also those that stand a good chance of being implemented, regardless of their acceptance by the scheme's stakeholders. This is demonstrated by choosing the conservation auction that was rejected by the farmers and won the acceptance of only half of the policy makers, but was nevertheless integrated into the project because it has already been institutionally established; and in the case of local organization-which was perceived by many interviewees as contributing to the effectiveness of the scheme, but was not included in the project because it contradicted the customary institutional framework in Israel.

Another finding regarding the feasibility of implementation is the contradictions found between the acceptance of instruments by farmers and policy makers, which may reflect more general disagreements between the farmers and the public at large. The policy makers in our survey were more supportive of market-based instruments than the farmers, and the question then arises which group should be consulted when designing agri-environmental schemes.

Following the course of our conceptual framework leads us to the conclusion that a reasonable criterion such as improving the ecological and economic effectiveness of a policy does not necessarily lead to higher chances of its implementation, at least in Israel. Institutional feasibility and acceptance by the relevant stakeholders constitute stronger criteria for the development of agri-environmental policy measures, and should be taken into account in their design.

Acknowledgments We are grateful to the Minerva Stiftung, Gesellschaft für die Forschung m.b.H. for financially supporting this study; to the Israeli Ministry of Agriculture, Ministry of Environmental Protection and the Jewish National Fund and the Nekudat Hen program for supporting the pilot project; to the Megido Regional Council for implementing the project; to Dr. Haim Zaban and Zvika Orr for their assistance and advice. We would also like to thank 3 anonymous reviewers for their helpful comments to an earlier version of this paper.

Open Access This article is distributed under the terms of the Creative Commons Attribution Noncommercial License which permits any noncommercial use, distribution, and reproduction in any medium, provided the original author(s) and source are credited.

\section{References}

Applebaum L (2002) The regional council and the local committee: adjustment in the changing environment. The Floersheimer Institute for Policy Studies, Jerusalem (Hebrew)

Bauer S (2006) Back to principles: Dezentralisierung und Neuausrichtung der ländlichen Regionalpolitik. Agrarwirtschaft 55:137141 (German)

Baylis K, Peplow S, Rausser G, Simon L (2008) Payment for environmental services: a comparison of US and EU agrienvironmental policies. Ecological Economics 65:753-764

Bertke E, Gerowitt B, Hespelt SK, Iseelstein J, Marggraf R, Tute C (2005) An outcome-based payment scheme for the promotion of biodiversity in the cultural landscape. In: Lillak R, Viiralt R, Linke A, Geherman V (eds) Integrating efficient grassland farming and biodiversity-EGF 2005, Tartu, Estonia, pp 36-39

Bräuer I, Müssner R, Marsden K, Oosterhuis F, Rayment M, Miller C, Dodoková A (2006) The use of market incentives to preserve biodiversity. European Commission DG Environment Report 
ENV.G.1/FRA/2004/0081. http://ec.europa.eu/environment/enveco/ others/mbi.pdf. Accessed 1 December 2007

Briemle G (1999) Vereinfachte Ansprache von Extensivgrünland mittels Indikatorpflanzen. Zeitschrift für Kulturtechnik und Landentwicklung 40:34-37 (German)

Briemle G (2000) Ansprache und Foerderung von Extensive-Gruenland Neue Wege zum Prinzip der Honorierung oekologischer Leistungen der Landwirtscheft in Baden-Wuerttember. Naturschutz und Landschaftsplanung 32:171-175 (German)

CJC Consultants (2004) Economic evaluation of the Central Scotland Forest and Grampian Challenge Funds. Final report for Forestry Commission Scotland. http://www.forestry.gov.uk/pdf/FCchall enge.pdf/\$FILE/FCchallenge.pdf. Accessed 25 May 2009

Dobbs TL, Pretty JN (2004) Agri-environmental stewardship schemes and "multifunctionality". Review of Agricultural Economics 26:220-237

DSE (2008) BushTender: rethinking investment for native vegetation outcomes. The application of auctions for securing private land management agreements. http://www.dse.vic.gov.au/CA256 F310024B628/0/E8653777854ADDC8CA25747100005E2C/\$File/ BushTender_rethinking+investment_web.pdf. Accessed 18 August 2009

Eggers J (2005) Dezentralisierung der Agrarumweltmaßnahmen in der europäischen Agrarpolitik Hemmnisse eines institutionellen Wandels. Shaker Verlag, Aachen (German)

Egoz S (1996) Israel's citrus grove landscape-an opportunity to balance urbanization with cultural values. Landscape and Urban Planning 36:183-196

Engel S, Pagiola S, Wunder S (2008) Designing payments for environmental services in theory and practice: an overview of the issues. Ecological Economics 65:663-674

EU (2003) The Common Agricultural Policy and the Lisbon Strategy. Agriculture-the heartbeat of rural areas. http://ec.europa.eu/ agriculture/lisbon/index_en.htm. Accessed 10 March 2007

European Commission (2005) Agri-environment measures: overview on general principles, types of measures and application. European Commission, Brussels. http://ec.europa.eu/agriculture/ publi/reports/agrienv/rep_en.pdf. Accessed 6 February 2010

European Commission (2006) Agriculture and the environment. http://ec.europa.eu/agriculture/envir/cap/index_en.htm. Accessed 6 February 2010

Feitelson E (1999) Social norms, rationales and policies: reframing farmland protection in Israel. Journal of Rural Studies 15: 431-446

Ferraro PJ (2008) Asymmetric information and contract design for payment for environmental services. Ecological Economics 65:810-821

Ferraro PJ (2009) Global Conservation Payment Initiatives Internet Database. http://www2.gsu.edu/ wwwcec/special/ci/index.html. Accessed 12 June 2009

Fleischer A, Tsur Y, Sidi A (1997) Measurement of the economic value of agricultural areas a tourist resource. Israel Ministry of Agriculture, Rehovot (Hebrew)

Frenkel A (2001) Open space vs. development: the loss of agricultural lands in Israel. Israeli Ministry of Agriculture and Rural Development and the Center for Urban and Regional Studies, The Technion I.T.T (Hebrew)

Gal R (2003) The Neglect of Agricultural Land in Moshavim in the 1990s, A dissertation submitted to the senate of the University of Tel Aviv, In partial fulfillment of the requirements for the degree of Doctor of Philosophy, Graduate Program in Geography (Hebrew)

Gerowitt B, Bertke E, Hespelt SK, Tute C (2003a) Towards multifunctional agriculture-weeds as ecological goods? Weed Research 43:227-235
Gerowitt B, Isselstein J, Marggraf R (2003b) Rewards for ecological goods-requirements and perspectives for agricultural land use. Agriculture, Ecosystems and Environment 98:541-547

Gomez JA, Romero P, Giraldez JV, Fereres E (2004) Experimental assessment of runoff and soil erosion in an olive grove on Vertic soil in southern Spain as affected by soil management. Soil Use and Management 20:426-431

Groth M (2007) Ausschreibungen in der Agrarumweltpolitik: Konzeption und Ergebnisse der praktischen Umsetzung eines Modellvorhabens. Perspektiven der Wirtschaftspolitik 8: 279 292 (German)

Hampicke U (2006) Jeder Markt honoriert nicht den Aufwand, sondern das Ergebnis. BfN-Skripten 179:161-172 (German)

ICBS (2005) Local authorities in Israel. http://www1.cbs.gov. il/www/publications/local_authorities2005/local_authorities_h. htm. Accessed 21 November 2007

ICBS (2006) Statistical Abstract of Israel 2006

ICBS (2008) Statistical Abstract of Israel 2008. http://www.cbs. gov.il/reader/shnaton/templ_shnaton.html?num_tab=st19_04\&C Year=2008. Accessed 29 January 2009

IDB (2006) The dairy industry in Israel 2006. http://www.israeldairy. com/info/dairy-farming/annrep2006.pdf. Accessed 5 December 2007

Jack BK, Leimona B, Ferraro PJ (2008) A revealed preference approach to estimating supply curves for ecosystem services: use of auctions to set payment for soil erosion control in Indonesia. Conservation Biology 23:359-367

Kaplan M (2004) Bikat HaNadiv Environs-master plan and partial district outline plan. The Ministry of the Interior-The Planning Administration (Hebrew with English abstract)

Kirwan B, Lubowski RN, Roberts MJ (2005) How cost-effective are land retirement auctions? Estimating the difference between payments and willingness to accept in the conservation reserve program. American Journal of Agricultural Economics 87:1239-1247

Kleijn D, Sutherland WJ (2003) How effective are European agrienvironment schemes in conserving and promoting biodiversity? Journal of Applied Ecology 40:947-969

Kleijn D, Baquero RA, Clough Y, Diaz M, De Estaban J, Fernandez F, Gabriel D, Herzog F, Holzschuh A, Joehl R, Knop E, Kruess A, Marshall EJP, Steffan-Dewenter I, Tscharntke T, Verhulst J, West TM, Yela JL (2006) Mixed biodiversity benefits of agrienvironment schemes in five European countries. Ecology Letters 9:243-254

Klimek S, Richter gen, Kemmermann A, Steinmann H-H, Freese J, Isselstein J (2008) Rewarding farmers for delivering vascular plant diversity in managed grasslands: a transdiciplinary casestudy approach. Biological Conservation 141:2888-2897

Lasanta T, Garcia-Ruiz JM, Perez-Rontome C, Sancho-Marcen C (2000) Runoff and sediment yield in a semi-arid environment: the effect of land management after farmland abandonment. Catena 38:265-278

Latacz-Lohmann U, Schilizzi S (2005) Auctions for conservation contracts: a review of the theoretical and empirical literature. The Scottish Executive Environment and Rural Affairs Department

Latacz-Lohmann U, Van der Hamsvoort C (1997) Auctioning conservation contracts: a theoretical analysis and an application. American Journal of Agricultural Economics 79:407-418

Latacz-Lohmann U, Van der Hamsvoort C (1998) Auctions as a means of creating a market for public goods from agriculture. Journal of Agricultural Economics 49:334-345

Lowell K, Drohan J, Hajek C, Beverly C, Lee M (2007) A sciencedriven market-based instrument for determining the cost of environmental services: a comparison of two catchments in Australia. Ecological Economics 64:61-69 
Marggraf R (2000) Agriculture and the environment. In: Tangermann $S$ (ed) Agriculture in Germany. DLG-Verlag, Frankfurt, pp 231-254

Marggraf R (2003) Comparative assessment of agri-environmental programmes in federal states of Germany. Agriculture, Ecosystems and Environment 98:507-516

Matzdorf B (2004) Ergebnisorientierte Honorierung ökologischer Leistungen der Landwirtschaft. UWSF-Z Umweltchem, Ökotox, pp 1-10 (German)

Mello I, Heissenhuber A, Kantelhard J (1998) Das Conservation Reserve Program der USA-eine Möglichkeit zur effizienten Entlohnung von Umweltleistungen der Landwirtschaft? Berichte über Landwirtschaft 80:85-93 (German)

Misgav A (2000) Visual preference of the public for vegetation groups in Israel. Landscape and Urban Planning 48:143-159

MOAG (2004) Concentration of data about agriculture and the countryside 2001-2002. Israeli Ministry of Agriculture and Rural Development, Rural Planning and Development Authority, Center for Information and Mapping (Hebrew)

MOAG (2006) Economic report on agriculture and the countryside 2005. Israeli Ministry of Agriculture and Rural Development, Rural Planning and Development Authority, Bet Dagan (Hebrew)

MOEP (2007) Web site of the Israeli Ministry of Environmental Protection. http://www.sviva.gov.il. Accessed 10 February 2007 (Hebrew)

Müller K, Toussaint V, Bork H-R, Hagedorn K, Kern J, Nagel UJ, Peters J, Schmidt R, Weith T, Werner A, Dosch A, Piorr A (2002) Nachhaltigkeit und Landschaftsnutzung. Neue Wege kooperativen Handelns. Margraf Verlag (German)

Musgrave RA (1956/57) A multiple theory of budget determination. Finanzarchiv 17:3-33

Musters CJM, Kruk M, De Graaf HJ, Ter Keurs WJ (2000) Breeding birds as a farm product. Conservation Biology 15:363-369

Natan G (2007) Governmental support for agriculture-a comparing survey. The Knesset-Center for Research and Information, Jerusalem

Newig J, Pahl-Wostl C, Sigel K (2005) The role of public participation in managing uncertainty in the implementation of the Water Framework Directive. European Environment 15: 333-343

OECD (2005) Evaluating agri-environmental policies: design, practice and results. Organisation for Economic Co-Operation and Development, Paris

OECD (2006) Agricultural policies in OECD countries: at a glance2006 edition. http://www.oecd.org/document/4/0,2340,en_2649_ 33727_36967364_1_1_1_1,00.html. Accessed 16 November 2007

Oppermann R, Gujer HU (2003) Artenreiches Grünland. Ulmer, Stuttgart (Hohenheim)

Pe'er G, Kark S , Benyamini D (2006) Butterfly diversity and conservation in agricultural landscapes across the climatic gradient in Israel: incorporating behavioral mechanisms. Nekudat Chen Fund. http://www.nekudat-hen.org.il. Accessed 18 August 2009 (Hebrew with English abstract)

Poyatos R, Latron J, Liorens P (2003) Land use and land cover change after agricultural abandonment. Mountain Research and Development 23:362-368

Prager K, Freese J (2009) Stakeholder involvement in agri-environmental policy making-learning from a local- and a state-level approach in Germany. Journal of Environmental Management 90:1154-1167

Preiss E, Martin JL, Debussche M (1997) Rural depopulation and recent landscape changes in a Mediterranean region: consequences to the breeding avifauna. Landscape Ecology 12:51-61
Romero-Calcerrada R, Perry GLW (2004) The role of land abandonment in landscape dynamics in the SPA 'Encinares del rio Alberche y Cofio, Central Spain, 1984-1999. Landscape and Urban Planning 66:217-232

Rueffer C (2007) Merit goods determined by society value judgments-political implications for public participation: support from an empirical analysis concerning environmental goods. $\mathrm{PhD}$ dissertation, Department of Agricultural Economics and Rural Development. Goettingen University, Goettingen, p 185

Schilizzi S, Latacz-Lohmann U (2007) Assessing the performance of conservation auctions: an experimental study. Land Economics $83: 497-515$

Schwarz G, Moxey A, McCracken D, Huband S, Cummins R (2008) An analysis of the potential effectiveness of a Payment-byResults approach to the delivery of environmental public goods and services supplied by Agri-Environmental Schemes. http://lupg62. wisshost.net/pdf/LUPG_Payment_by_Results_Feb09.pdf. Accessed 6 February 2010

Scozzafava S, de Sanctis A (2006) Exploring the effects of land abandonment on habitat structures and on habitat suitability for three passerine species in a highland area of Central Italy. Landscape and Urban Planning 75:23-33

Shalev G (1989) Government contracts in Israel. Public Contract Law Journal 18:34-53

Shemesh-Adani O (2003) The economic value of agricultural landscapes. MSc thesis, The Department of Agriculture, Food and Environment. The Hebrew University, Rehovot (Hebrew)

Shirizly Y (2001) Public attitude toward visual quality of open spaces in Israel. MSc thesis, Department of Geography and Human Environment. Tel Aviv University, Tel Aviv (Hebrew)

Smith KR (2006) Public payments for environmental services from agriculture: precedents and possibilities. American Journal of Agricultural Economics 88:1167-1173

Soen D (1997) Planning and mediation-democratic theory and public participation in Israel. Ekistics 382:60-63

Sofer M, Applebaum L (2006) The rural space in Israel in search of renewed identity: the case of the Moshavim. Journal of Rural Studies 22:323-336

Stoneham G, Chaudhri V, Ha A, Strappazzon L (2003) Auctions for conservation contracts: an empirical examination of Victoria's Bush Tender trial. The Australian Journal of Agricultural and Resource Economics 47:477-500

von Haaren C, Bathke M (2008) Integrated landscape planning and remuneration of agri-environmental services-results of a case study in the Fuhrberg region of Germany. Journal of Environmental Management 89:209-221

von Haaren C, Bills N (2007) Agri-environmental programs in the US and the EU: lessons from Germany and New York State. Working paper. Accessed 20 May 2009. http://nercrd.psu.edu/ TALUC/PowerPoints/BillsvHaaren.pdf

Wittig B, Richter-Kemmermann A, Zacharias D (2006) An indicator species approach for result-orientated subsidies of ecological services in grasslands-a study in Northwestern Germany. Biological Conservation 133:186-197

Wunder S, Engel S, Pagiola S (2008) Taking stock: a comparative analysis of payment for environmental services programs in developed and developing countries. Ecological Economics 65:834-852

Zaban H, Feller N, Amdur L, Avnimelech Y, Aylon O (2004) Sustainable agriculture - an approach for preserving Israel's open space values. Forest: Journal of Forests, Woodlands and Environment 5-6:26-32 (Hebrew with English abstract)

Zabel A, Holm-Mueller K (2008) Conservation performance payments for carnivore conservation in Sweden. Conservation Biology 22:247-251 